\title{
The Figure of the Teacher-Prosumer for the Development of an Innovative, Sustainable, and Committed Education in Times of COVID-19
}

\author{
Laura Triviño-Cabrera *(D), Elisa Isabel Chaves-Guerrero and Laura Alejo-Lozano (D) \\ Faculty of Educational Sciences, Teatinos Campus, University of Malaga, 29071 Málaga, Spain; \\ echaves@uma.es (E.I.C.-G.); laura@uma.es (L.A.-L.) \\ * Correspondence: laura.trivino@uma.es
}

Citation: Triviño-Cabrera, L.;

Chaves-Guerrero, E.I.; Alejo-Lozano,

L. The Figure of the Teacher-Prosumer for the Development of an Innovative, Sustainable, and Committed Education in Times of COVID-19. Sustainability 2021, 13, 1128. https://doi.org/

$10.3390 /$ su13031128

Academic Editor: José

Antonio Marín-Marín

Received: 13 December 2020

Accepted: 18 January 2021

Published: 22 January 2021

Publisher's Note: MDPI stays neutral with regard to jurisdictional claims in published maps and institutional affiliations.

Copyright: (c) 2021 by the authors. Licensee MDPI, Basel, Switzerland. This article is an open access article distributed under the terms and conditions of the Creative Commons Attribution (CC BY) license (https:/ / creativecommons.org/licenses/by/ $4.0 /)$.
Abstract: Studies on the adaptation from face-to-face to online teaching during lockdown show the before and after in education that faces the double challenge of promoting digital skills and public access to connectivity and electronic devices in the post-COVID-19 era. Therefore, this article contributes to these new emerging lines of educational research by presenting an educational innovation project called "Teachers Versus COVID-19". This project aimed to verify whether the figure of teacher-prosumer, that is, consumers of media culture and creators of their own educational resources, favors the initial training of teachers during the pandemic. To this end, the following objectives were proposed: firstly, test whether the figure of the teacher-prosumer contributes to improving the adaptation of face-to-face teaching to the virtual modality of the Didactics of Social Sciences in the Degree in Primary Education during lockdown; secondly, analyze the production of content on social networks by the students in the Degree in Primary Education, according to the objectives of sustainable development. To validate our teacher-prosumer proposal, we chose the design-based research (DBR) qualitative methodology. For this, 240 students from the course in Didactics of Social Sciences of the Degree in Primary Education at the University of Malaga created 37 educational videos that teach the social sciences curriculum to children between 6 and 12 years of age from the perspective of relevant social problems and the Sustainable Development Goals. These videos were disseminated through the project's YouTube channel. The results of this study corroborate the effectiveness of turning students into teachers-prosumers, generating the development of critical, creative, digital, and socio-emotional skills so that they feel committed to playing an active role in social changes for a sustainable world.

Keywords: teacher training; COVID-19; sustainability

\section{Introduction}

\subsection{The Figure of the Teacher-Prosumer}

The present work is part of a research project which, in its first phase, had focused on studying the ways in which future teachers "use" networks, as well as analyzing social networks as emerging cultural industries, and exploring the possibility of using them as elements of audiovisual literacy for the promotion of civic values [1,2]. To do so, produsage (production and use) practices in social networks were taken into account as actions carried out by people who assume the double role of producers and users [3].

Participation of people in social networks has to do with their status as produsers; that is, with the fact that a certain fusion between production and use is inevitable in that environment, as participants play the double role of producers and users. Much of this produsage has to do with the introduction of the online self in its different aspects, including the creation of the self as a private label or the introduction of a reflective subject [4]. Currently, the new audiovisual formats produced by young people on the 
networks have broken the "creator-cultural content distribution company-consumers" cycle and propose a new distribution and consumption model.

University students who come to our classrooms have internalized information technologies since childhood, developing new habits to spend their time or the processes to obtain information. These changes run parallel to the transformation of the communication paradigm and its principles around technological advancements, consumer culture, and globalization that have been replaced by criteria of immediacy, accessibility, and sensory satisfaction [5].

We are entering a new scenario for interpersonal relationships, where young people find the motivation to communicate in social networks, in a way which is very different from the traditional one. Millennials have experienced the rise and mass of ICTs during their adolescence, which are increasingly mobile. Having grown up at the same time that these devices were being introduced in homes in a generalized way, these young people have become expert users in learning and internalizing technologies and their applications [6].

Millennials were the first teenagers to extensively acquire mobile phones during their final school years. This made the adaptation of young people to the technological development of mobile devices possible. With the avant-garde advances in mobile telephony and the Internet, phones were complemented by multiple applications that have come to cover absolutely all the communication needs of people [6]. These great technological changes at an age that is so permeable to education and personality development have given rise to a generation that has rapidly absorbed technological devices as an indispensable part of their daily lives. The same technological advances have also brought about a change in social configuration, in patterns of social behavior and personal interaction, and in the way in which young people look at and approach the world. This generation increasingly expresses its intimacy on the networks and exposes values of the private sphere in the public sphere [7].

According to the Internet Users Survey of the AIMC (Association for Media Research) [8], Facebook is currently the most used social network in Spain for $87 \%$ of the participants. On the other hand, and according to data from the AIMC itself, Instagram has 12 million users in Spain. The 700 million people who are part of the Instagram community share 95 million photos and videos daily. In addition, $40.1 \%$ of the users declared that they follow Youtubers, $16.3 \%$ of them regularly.

Watching YouTube and other social media videos is the second most common practice on the Internet $(83.4 \%)$, only behind reading current news (85.5\%). However, other reports by AIMC itself show that the consumption of videos from YouTube is practically five times the browsing of the most searched digital newspaper. The figures given partially justify the choice of our object of study, but the main reason for taking into account these spaces of interaction is that, as research carried out by the [9] Royal Society for Public Health concludes, among other positive and negative aspects, young people highlight the importance of Facebook, Instagram, and YouTube for self-expression and the construction of identity.

Therefore, there is a digital divide between those who teach and the younger generation. This gap is partially due to the fact that the culture they consume is conceived as something inferior, popular in a derogatory sense [10]. The author himself [11], to counter the simplistic idea that youth is a group of innocents exploited by commercial culture, raises the ambivalence of adolescent culture, which he defines as a contradictory mixture of the authentic and the manufactured, an area of self-expression as well as a space of which the commercial purposes take advantage. Based on this definition, one of our premises is that popular culture must also be understood as pedagogy [12], as the cornerstone of a media education that makes those who experience it the protagonists. Audiovisual production in social networks can be approached from different educational contexts, preparing students for produsage and giving meaning to these practices also within the classroom. Popular culture as a pedagogy prepares students for critical literacy 
and Freirian critical pedagogy [13], which allows us to claim and question the products of a media culture in which we participate and consume, as well as the pleasant dimension and the meaning we give to cultural products [11].

Bearing in mind this panorama, we develop the second phase of the research by introducing the produsage in the initial training of the teaching staff for two fundamental reasons: the study of the degree of effectiveness of the media culture as an educational tool in the teaching-learning processes and the use of social networks and the application of digital technologies as allies in the face of unexpected virtual teaching during lockdown. Thus, the figure of the students of the Degree in Primary Education emerged as teachers in initial training-prosumer, that is, consumer and producer of Social Sciences content on social networks.

\subsection{The Educational Innovation Project "Teachers Versus COVID-19"}

"Teachers Versus COVID-19" (Figure 1) is a project about innovation in education which is focused on turning students $(\mathrm{N}=240)$ from the compulsory subject Didactics of Social Sciences of the Degree in Primary Education into teachers-prosumers. That means creators of content through the YouTube social network and intended to teach Social Sciences to primary school students aged between 6 to 12 during lockdown.

\section{Docentes Versus Covid-19}

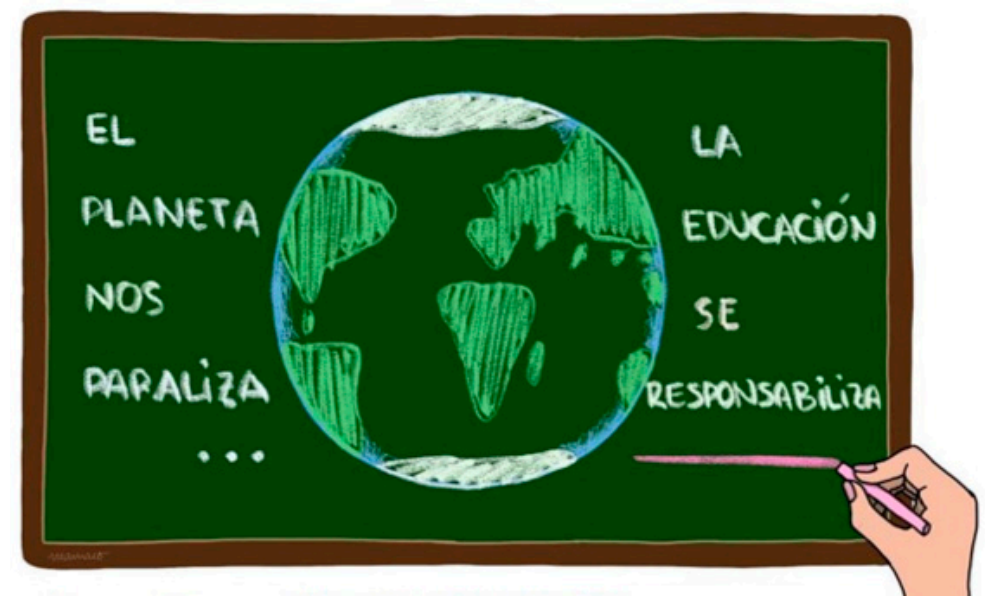

Figure 1. Visual identity of the project "Teachers Versus COVID-19": Our planet stops, Education takes responsibility (El planeta nos paraliza, la Educación se responsabiliza).

The teaching of the social sciences curriculum was considered for the creation of the content from the perspective of relevant social problems and the commitment to incorporate the Sustainable Development Goals. Focusing on relevant social problems [14-18] it helps students to take an active role in building the future and to be committed both socially and politically [19]. In addition, it also induces the students to develop critical thinking [19] through teaching-learning processes of social sciences which promote the ability to critically assess their environment both locally and globally. Here, the relevant social issue established as the starting point was the COVID-19 pandemic context. This way, the importance of including curricular contents that are adapted to the circumstances and facilitate the students' understanding of the reality lived during lockdown was emphasized. An approach that had already been considered as good practice within the "School's Out, But Class's On" campaign of the Chinese education system that proposes to:

Coordinate curriculum learning and special education to fight against the "epidemics", and strengthen the guidance of patriotism education. It focuses on the education of advanced deeds and epidemic prevention knowledge, life education, public safety education, and mental health education as important learning content. It guides students to correctly understand the relationship between humans, 
society, and nature, to respect the objective world, and to act in a scientific and rational way. [20]

We determined that the productions would be added to the United Nations Organization's Be the Change initiative, which considers that each person must incorporate the SDGs into their daily lives to achieve a happier and healthier world by 2030. This purpose is ideal for the situation that we teachers and students are going through during lockdown. The United Nations General Assembly approved the 2030 Agenda for Sustainable Development with the purpose of establishing a plan of action in favor of the people, the planet, and prosperity by strengthening universal peace and eradicating poverty. This all constitutes the greatest challenge and fundamental requirement for sustainable development [21], which includes the economic, social, and environmental dimensions that would have a global scope through the realization of a set of Sustainable Development Goals (SDGs) focused on these arguments.

We resolve, between now and 2030, to end poverty and hunger everywhere; to combat inequalities within and among countries; to build peaceful, just, and inclusive societies; to protect human rights and promote gender equality and the empowerment of women and girls; and to ensure the lasting protection of the planet and its natural resources. We resolve also to create conditions for sustainable, inclusive, and sustained economic growth, shared prosperity and decent work for all, taking into account different levels of national development and capacities. [21]

In the case of the SDGs, the teaching team decided that the students should determine the objective or objectives that best fit the issues raised in their respective videos.

In a similar way, the project itself aimed to respond to SDG 4 following the principle to "Ensure inclusive and equitable quality education and promote lifelong learning opportunities for all"; which could be diminished by the period of lockdown as the main preventive measure against COVID-19. Therefore, "Teachers Versus COVID-19" assumed a problem that needed an urgent response from the teaching team: the digital divide and technological gap; and, therefore, the educational and social gap.

Thanks to the information received by email and from the different virtual tutorials, we detected the difficulties our students face in monitoring virtual and online teaching as they may not have a suitable internet connection and/or technological resources at their homes. In this regard, reports and studies [22-30] must be taken into account because they make us aware of how the pandemic has shown and considerably increased the differences that already existed between students of different socioeconomic and geographical origins; the rich and the poor, those who come from urban or from rural areas. For our students, a lesser or greater adaptability to online teaching depended on whether the home had adequate connectivity and was equipped with enough electronic devices. There were some students that were unable to connect as they shared their laptops with other family members working remotely from home. In other cases, students living in remote areas did not have effective connectivity.

This situation demonstrated the need and importance of the development of this project, which was made of a combination of collaborative-cooperative learning, since the production of educational videos was programmed as a group task. This way groups of students could distribute the tasks according to the personal, familiar, and professional circumstances of the members. Certain students that had difficulties in connecting to some classes would not stop attending them thanks to the collaborative networks their classmates had created, such as monitoring teaching through WhatsApp groups.

For a project of such magnitude, service-learning was used as a teaching method as it is the most suitable for a civic, responsible, and committed training to be implemented in different contexts [31]. Thus, while the students of the Degree in Primary Education were learning how to create educational resources for teaching social sciences in primary education, a service was established for the educational community, as these educational videos would help them understand the immediate reality in which girls and boys aged 6 to 12 were living during lockdown. 


\subsection{Research Question and Aims}

The research question addressed in this paper is the following: Can the teacherprosumer figure favor the initial training of teachers in Social Science Didactics from the perspective of the relevant social problems during the pandemic? Based on this question, we determine two specific objectives:

SO1 Test whether the figure of the teacher-prosumer contributes to improve the adaptation of face-to-face teaching to the virtual modality of the Didactics of Social Sciences in the Degree in Primary Education during lockdown.

$\mathrm{SO} 2$ Analyze the production of content on social networks by the students in the Degree in Primary Education, according to the objectives of sustainable development.

\section{Materials and Methods}

The research method is framed within the design-based research (DBR), a qualitative methodological paradigm with a holistic approach seeking to develop and put theory into practice simultaneously through the design of innovative learning environments and the research on why and how they work. According to Anderson [32], this method was born to produce specific changes in educational systems and establish a bridge between educational theory and practice. In the most recent literature, Easterday, Rees Lewis, and Gerber [33] propose a definition:

Educational design research is a meta-methodology conducted by education researchers to create practical interventions and theoretical design models through a design process of focusing, understanding, defining, conceiving, building, testing, and presenting, that recursively nests other research processes to iteratively search for empirical solutions to practical problems of human learning [33] (p. 151).

Before reaching this definition, some publications [34-40] coincided in establishing their objective as the improvement of didactic interventions by providing new solutions and theories to respond to a practical, existing, and real educational problem. In this case, there was a need to adapt the subject of Didactics of Social Sciences to the emergency remote learning, due to the lockdown established by the COVID-19 pandemic.

Cob et al. [41] define DBR as the continuous interrelation of the development of both theory and intervention, in such a way that interventions are designed to develop a theory, and not simply test its effectiveness. Starting from the research question, a review of the bibliography is carried out; data are collected and then analyzed to build an explanatory theory. The method described here is an increasingly applied methodological paradigm. Van den Akker [42] established four areas of educational research where DBR has been put into practice: curriculum, media and technology, instruction and learning, and didactics and teacher training. In the present work, all of these areas of educational research are addressed. The research procedure has been developed according to the iterative phases that Easterday et al. [33] established as parts of the design-based research process. In the following graph (Figure 2), we can see how, following this iterative nature, repetitions of some of the phases are allowed, specifically of the "Test" phase.

- $\quad$ Focus. During the focus phase, the purpose of the project was defined after the analysis of the educational needs and the identification of the problem. In this case, the problem arising from the lockdown decree due to the outbreak of the COVID-19 pandemic originated the sudden need to adapt teaching to the situation. Opportunities that could be addressed through the solution of the problem were also taken into account. Considering all this, the purpose of the project was established in adapting the subject to emergency remote learning and promoting the figure of teachers-prosumers for the teaching of social sciences through SDGs and COVID-19 issues. Given that the teaching team involved in this project had four class-groups assigned to them, a convenience sample was selected, consisting of $\mathrm{N}=240$ students (155 female students and 85 male students), aged 22 to 23 years old, who were taking the compulsory course Didactics of Social Sciences of the Degree in Primary Education at the Univer- 
sity of Malaga during the second semester of the 2019/2020 academic year. These 240 students were organized into 37 working groups of between 5 to 8 members.

- Understand. During this phase, learners, contexts, and existing solutions were studied. As the beginning of this course coincided with the beginning of the period of lockdown, the teaching team did not know the students personally; so a forum was built in the virtual campus of the course where we could introduce ourselves and freely comment on how we were emotionally coping with the situation we were living in. Based on the testimonies, we set the profile of the students in three categories associated with the context of the pandemic: students not affected by COVID-19; students with relatives affected (even hospitalized) by COVID-19; and students with relatives in the front line. On the other hand, an open-ended questions survey was designed as a pre-test with the aim of getting to know the students' previous ideas through an empirical data collection method, specifically, their opinion on the social problems of the COVID-19 pandemic, or their possible active role in improving the social problems derived from COVID-19. In addition, the revision of the literature led to a process of documentation on theories and models of teaching and learning that would help understand the problem through the analysis of other solutions applied to similar problems. Finally, the students carried out a critical literacy process through a group activity based on the creation of a list of content for the Primary Education Curriculum related to the problem of COVID-19 that could be addressed through social sciences at all levels and in all year groups in primary education.

- Define. In this phase, the research question and the learning goals were defined. It was decided that the research question generated by the problem studied is the following: Can the teacher-prosumer figure favor the initial training of teachers in Social Science Didactics from the perspective of the relevant social problems during the pandemic? The learning goals were based on the development of critical, historical, geographical, social-citizen, empathic, media, audio-visual, and digital competencies.

- Conceive. In the conceive phase, the designer teaching team proposed the solution to the problem established in the define phase. The plan designed to achieve the objectives consisted of suggesting that students designed educational videos aimed at Primary Education students and addressed relevant social problems from the didactics of Social Sciences according to the SDGs. In order to do this, the students prepared a written explanatory document about the educational video that included the organization and distribution of roles and tasks to be carried out, as well as a transcript of the audio-visual script.

- Test. In this phase, the teaching team evaluated the effectiveness of these scripts and the achievement of the learning goals, in order to test the effectiveness of the theory. This phase is iterative and has the purpose of testing the procedure in order to achieve the improvement of the resulting educational material in the next phase. Testing during the design process of teaching materials, without waiting for them to be finished, is an inherent characteristic of educational design-based research.

- Build. In this phase, the students as designers and teachers-prosumers created educational videos ( $3-5$ min long) in different formats explaining the problem of COVID-19 through the teaching of social sciences.

- Test. The effectiveness of the solution to the educational problem is evaluated in this new phase of the Test. To do this, this phase was divided into two testing procedures: assessment and post-test. For the assessment procedure, the students carried out an open survey in order to test the achievement of the learning goals, the effectiveness of the educational videos and their assessment of the project. This open survey would be used to collect data and submit them to three evaluation procedures: individual selfevaluation, group co-evaluation, and evaluation of the teaching team. The questions for the open survey were the following (Table 1). 
Table 1. Evaluation procedures.

\section{Self-Evaluation}

1. Define with a sentence what the project Teachers vs. COVID-19 meant to you.

2. How can your video be an educational resource for the teaching-learning process of Social Sciences in the context of the COVID-19 pandemic?

3. Self-evaluate and rate your participation in the Teachers vs. COVID-19 project.

\section{Co-Evaluation}

1. Evaluate and rate your own colleagues in your workgroup for participation in the Teachers vs. COVID-19 project. Justify your answer

2. After viewing the videos uploaded to the YouTube channel "Teachers vs. COVID- 19", select one of the videos of your group-class (your own video is not admissible) that, in your opinion, represents a good educational resource for the teaching-learning process of Social Sciences.

3. Would you like to use your video or that of other colleagues in your training internship, as an educational resource?

\section{Evaluation of the Teaching Team \\ 1. Evaluate the teaching team.}

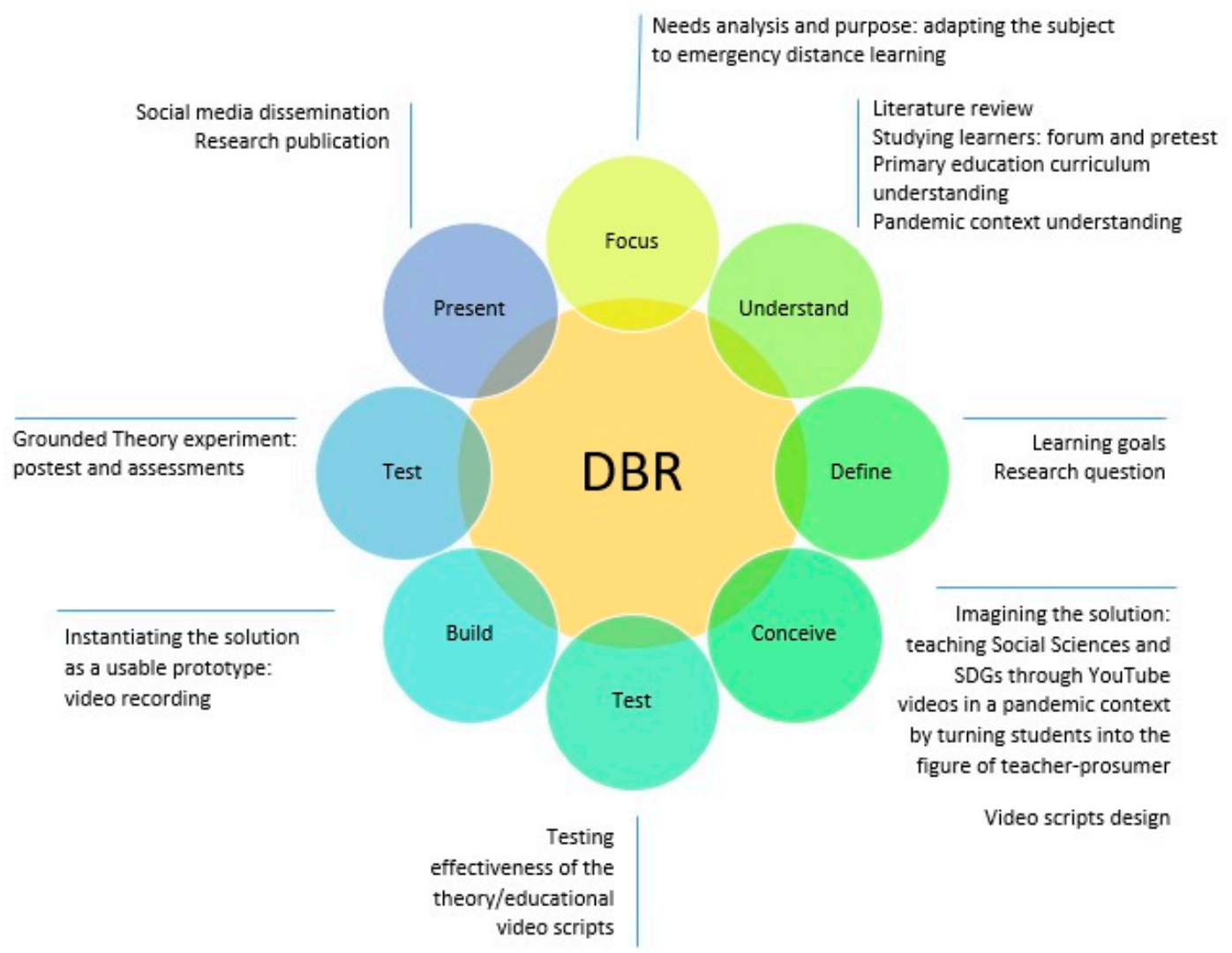

Figure 2. Design-based research (DBR) process iterative phases based on Easterday, Rees Lewis, and Gerber [33].

In addition, the teaching team used a rubric to assess the degree of achievement of the learning goals set out through the videos, as well as their didactic dimension. It was evaluated using a Likert scale, from 1 (least relevant) to 5 (most relevant) and with the following items:

1. It is suitable for the association of the contents of the legislative curriculum of Social Sciences of Primary Education with relevant social problems. 
2. It includes Sustainable Development Goals.

3. It uses language adapted to the level of primary education.

4. It adjusts to the duration established ( $3-5 \mathrm{~min})$.

5. It uses freely accessible graphic resources.

6. It is based on scientific, reliable, and proven bibliographic sources.

7. It includes header and credits in the videos where all the information related to the organization of tasks and roles of the group members is shown.

8. It develops their creative ability.

In order to validate the theory proposed in this research, that is, the figure of the student-future teacher as teacher-prosumer, the data collected in the open pre/post-test questionnaires were examined with qualitative analysis based on an open system of categories and using NVivo and Microsoft Excel software. In this sense, the design-based research coincides with Grounded Theory [43] by understanding theory as a reflection interconnected with practical intervention, in which both data collection, analysis, and the resulting theory continually interrelate.

- Present. In this phase, educational videos are disseminated on social media (through the project's YouTube channel and Instagram account) with the aim of having this didactic material used in schools for face-to-face or virtual teaching. The designer students disseminated the videos in the schools where they had carried out their internships as teachers in training. They explained the value of educational videos to teach about the relevant social problems related to the pandemic from the social sciences perspective, taking into account the SDGs.

\section{Results}

As we have explained, two types of initial and final questionnaires were established. The pre-test consisted of a total of seven questions, divided into four topics: 1 . social sciences knowledge area (what, how, and why to teach social sciences), 2. relevant social issues and the COVID-19 pandemic (what relevant social issues concern them and what role they take during the pandemic), 3. media and social networks to access information, and 4. hobbies and skills. The post-test posed the previous questions plus two others associated with the following categories, contextualized within the "Teachers Versus COVID-19" project: 5. dissemination of the educational video in schools and 6. General evaluation of the "Teachers Versus COVID-19" project.

\subsection{Curriculum of Social Sciences and Relevant Social Problems}

Both in the pre-test and in the post-test, we verified that the students did not present any difficulties in identifying relevant social problems.

Firstly, we gathered some information about what students understood by relevant social problems before and after the start of the project by collecting information through the pre-test and post-test surveys (Figure 3). At the beginning of the State of Emergency, $33.3 \%$ of the students expressed their concern about the unprecedented situation caused by a "global crisis". However, this concern dropped to $21.6 \%$ after the project, coinciding with the end of the lockdown period. The "State of Emergency" was the second biggest concern, with $12.5 \%$, both in the pre-test and the post-test. Thirdly, "civic values", specifically in terms of health and safety standards and solidarity, were a concern to $11.25 \%$. Another $8.7 \%$ expressed some concern about "psychological consequences" before the start of the project, which fell to $5.8 \%$ after the start of the project. Likewise, both "public health" $(8.3 \%)$ and "mortality" (7\%) were a serious problem for students at the start of the project, but, in the post-test, only $3 \%$ maintained their concern with respect to public health, indicating the fact that the students considered that the healthcare situation had improved. At the start of the project, $8 \%$ considered "political ineffectiveness" as one of the most worrying issues, which fell to 3\% after the project, at the end of the State of Emergency. The hypothesis of zoonosis was considered acceptable by $4.6 \%$ of the students, meaning that the virus would 
have been genetically manipulated in a laboratory, a figure that decreased to $0.8 \%$ after the project.

\section{REFLECTIONS ON THE SOCIAL PROBLEMS OF COVID 19 (PRE-TEST AND POST-TEST)}

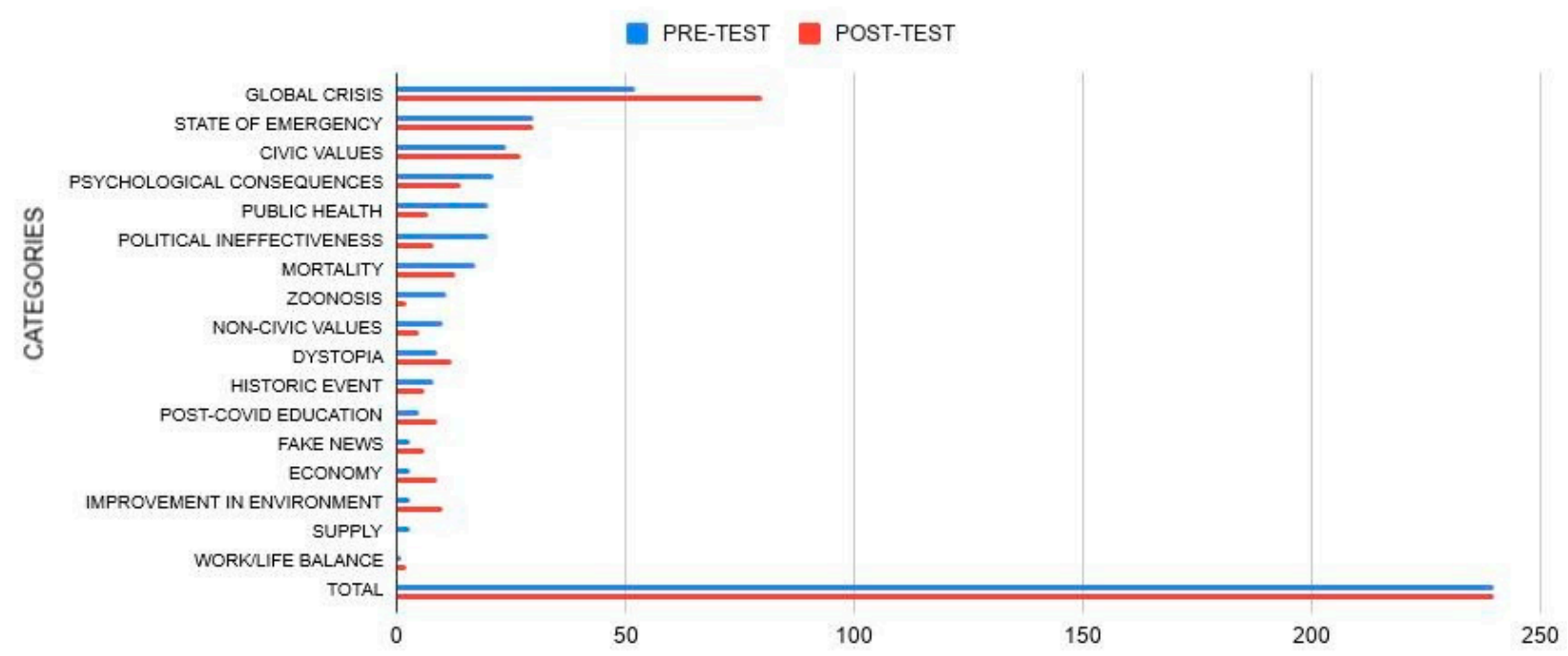

Figure 3. Students' opinions on the social problems of the COVID-19 pandemic.

Each of the following categories: civic values of society, reflection on current reality, either as a dystopia or as a historical event, as well as post-COVID-19 education, were concerns for $4 \%$ of the students at the beginning, falling to $2 \%$ after the project. It should be noted that fake news and the economy, identified at the beginning of the period by $1.25 \%$, were found to be problematic for $4 \%$ at the end of the project. At first, only $1.3 \%$ of the students said that the period of lockdown resulted in an improvement in the environment; the reduction of polluting gases caused by air, sea, land, and industrial transport and the appearance of animals in human habitats; this percentage increased to $6 \%$ after the project.

The students demonstrated that they could easily identify relevant social problems, but this was not the case when they were told that they had to teach social sciences from a choice of relevant social problems. The teaching team observed the students had some difficulties selecting the contents of the official curriculum of social sciences for primary education from the perspective of the social problem COVID-19. This is due to the fact that students failed to consider the teaching of curricular content beyond those established by the legislative curriculum and by the textbook itself. This is a traditional and conformist perception of the teaching of social sciences. As stated by Prats and Santacana [44], "a proper history teaching must provide the tools to understand social reality" (p. 17), therefore, the development of historical consciousness allows for a critical reflection on the past so that students are aware and responsible for their present actions [45].

Therefore, the suggestion to create an educational video that teaches official contents of social sciences at the same time that the relevant social problems derived from the pandemic are presented to boys and girls turned out to be motivating and easier to accept. In fact, adopting the figure of teacher-prosumer led to a change in the attitude of students in relation to their role in the face of the pandemic.

This is corroborated by the answers to the same question in the pre-test and in the post-test. Moreover, "Teachers vs. COVID-19" was designed to make students more active in relation to their experiences during lockdown. Therefore, one of the basic questions was: "Do you think that, as a primary education student and a future teacher, you can play an active role in improving the social problems of COVID-19?" (Figure 4). Of the students, $37 \%$ believed that the way they could contribute to this improvement was to raise awareness of health and safety guidelines to be followed to curb infections. Twenty- 
eight percent understood that their active role was channeled through volunteering and providing assistance to vulnerable people in their family and neighborhood, while $20.1 \%$ developed their role by providing teaching support to primary education pupils in their most recent work placement, or children in their social context. Of the students, $6 \%$ felt that this experience would provide them with knowledge that would be very useful for their future teaching career, together with $5 \%$ who understood their contribution as agents for the development of critical thinking in society. Finally, 3.7\% did not consider they could play any role in improving the COVID-19 problem, as they considered it was the responsibility of health professionals or politics.

Do you think that, as a student on the Degree in Primary Education and a future teacher, you can play an active role in improving the social problems of COVID-19?

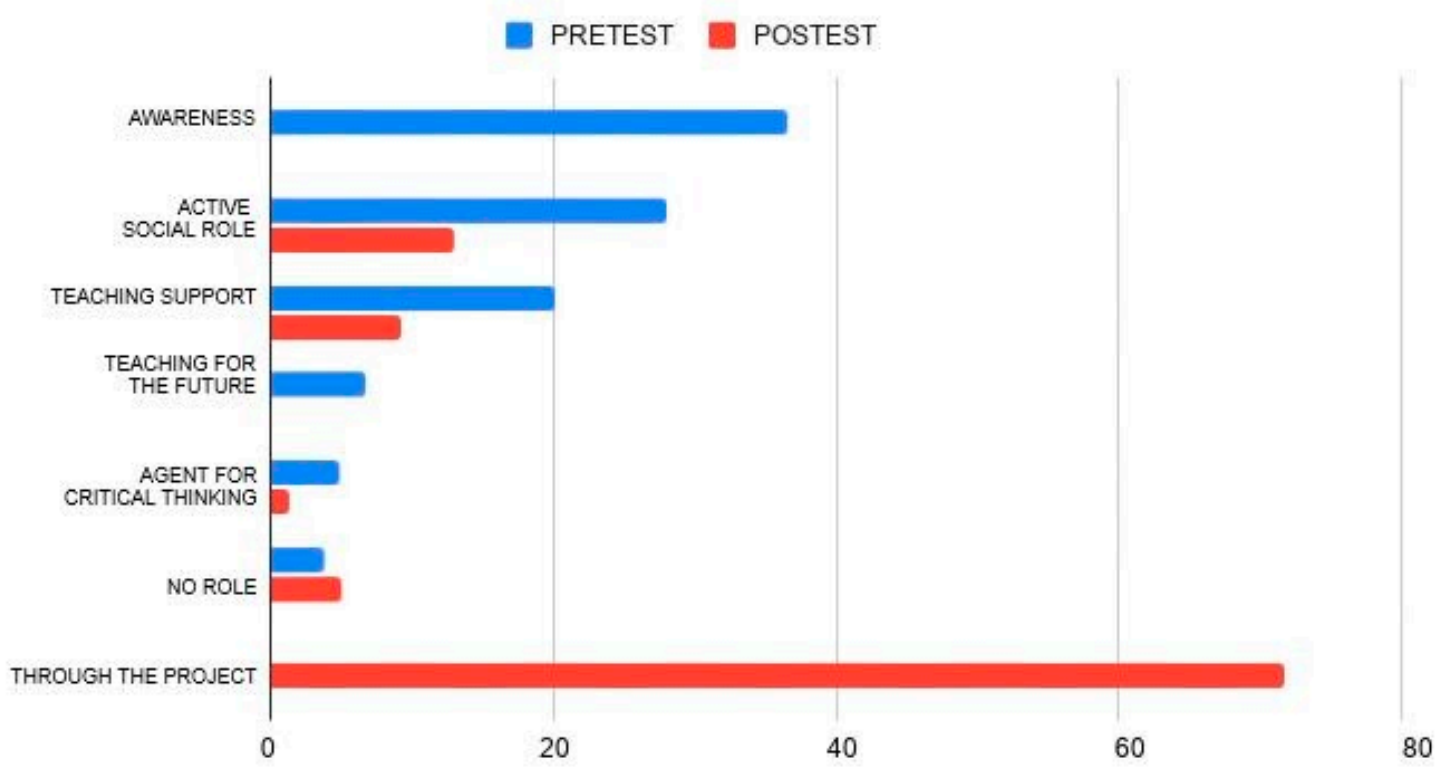

Figure 4. Students' opinion of their active role in improving the social problems of COVID-19.

After the project, $31 \%$ continued to focus on social volunteering and $22 \%$ understood their social participation in terms of providing educational support to primary school children in their immediate environment. It is interesting to note that the percentage of students who felt they could not contribute to lessen the problem slightly increased. This is probably due to a less positive mindset after nearly three months of lockdown. As for the majority, $73 \%$ stated that their active contribution to solve the problem was channelled into the design and creation of the educational video and from this percentage, $72.8 \%$ expressed the usefulness of the educational video in developing both critical awareness among primary school students and learning the social science content; $24 \%$ highlighted the educational benefits of sharing the video on social media; and $9.8 \%$ pointed to the innovative dimension of the resource as a new way of teaching social sciences. These analytical subcategories of the students' response, which considers the educational video as the means to lessen the problem, explain why the categories "awareness" and "teaching for the future" have disappeared in the graph corresponding to the post-test (Figure 3), since they are nullified by the students who understand the educational video as the ideal means to develop them in primary school pupils.

\subsection{Sustainable Development Goals and Creation of Audiovisual Content}

After selecting the contents and relevant social problems, it was proposed to determine how the audio-visual stories could be committed to some of the Sustainable Development Goals set by the United Nations. That is, each video should send a message of hope and commitment to our world. To do this, each group of students freely decided upon the SDGs 
that best fit the themes set in the video scripts. The 37 working groups participating in the “Teachers Versus COVID-19" project produced and broadcasted 37 educational videos on the YouTube channel [46]. The selected SDGs were the following in order from highest to lowest presence in the videos (Figure 5):

Higher impact: health and welfare $(89 \%)$, partnerships to achieve the goals $(86.5 \%)$; followed by responsible production and consumption $(70.2 \%)$ and peace, justice, and strong Institutions (65\%).

Average impact: decent work and economic growth (59.5\%), industry, innovation, and infrastructure (46\%), gender equality (40.5\%), climate action $(24.3 \%)$, and life of land ecosystems $(21.6 \%)$.

Less impact: clean water and sanitation and zero hunger (13.5\%); quality education, end of poverty, affordable and non-polluting energy and reducing inequalities (10.8\%); and sustainable cities and communities and underwater life (8\%).

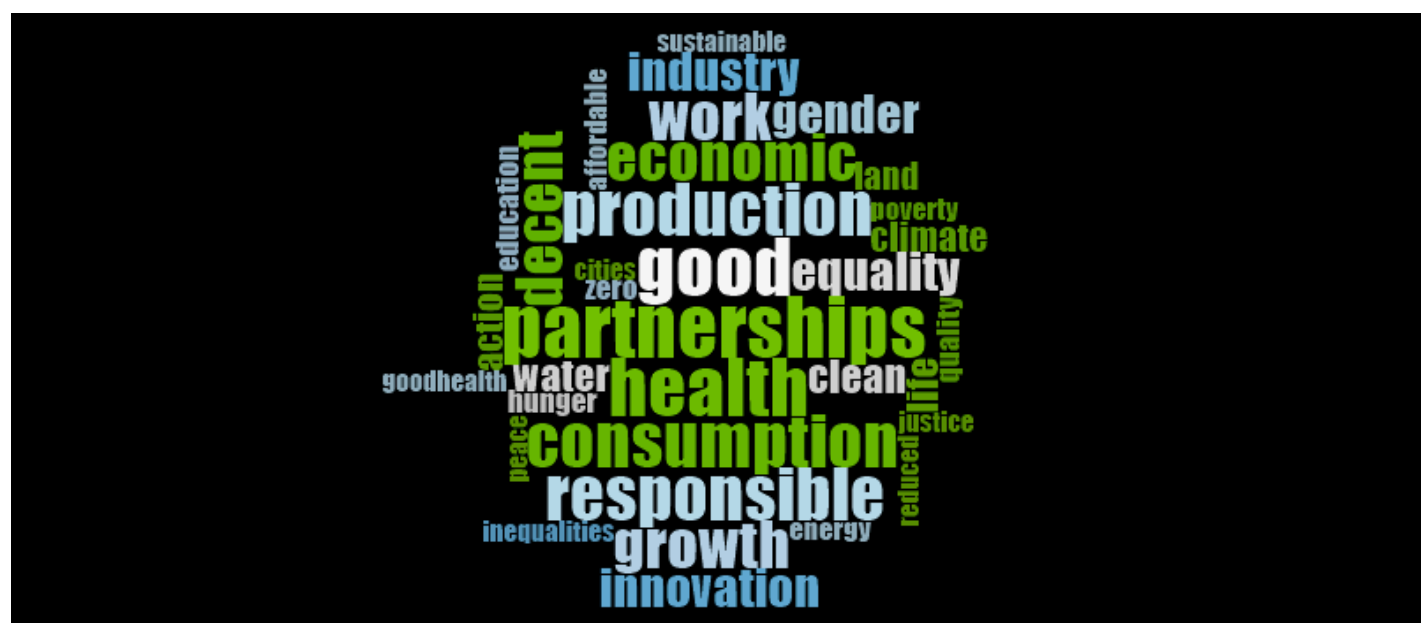

Figure 5. Sustainable Development Goals tackled in the project's educational videos.

In terms of production, regarding the format, the videos had to meet three fundamental requirements: to be adapted to primary school students aged 6 to 12; last 3 to $5 \mathrm{~min}$; and integrate a heading and credits with detailed information on the authors and their functions. Therefore, the type of video was a free choice. The different groups opted for typologies according to their respective hobbies and abilities. Students who could play instruments and sing opted for video clips, through which they both created their own songs and covered popular songs; video-gamer students created educational videos simulating video game scenarios; students who had acting as a hobby opted for the creation of videos where they became actors; or students with artistic gifts drew illustrations for their videos, etc. Taking into account the diversity of formats, we categorized the following typologies (Figure 6): informative, narrative, and historical animations, reports, video clips, illustrations, video games, interviews, motion graphic animations, whiteboard animation, and clip animation. Regarding the software used for the production of the videos, we can point out the following: Movie Maker, Powtoon, Imovie, Adobe Premiere, Filmora, Stopmotion, VideoScribe, Photoshop, Canva, Audacity, Minecraft, Goanimete, and Camtasia.

With regards to the dissemination of the videos, $52 \%$ of the students indicated that they had disseminated their videos in the primary schools where they had carried out their respective work placements (Practicum I, Practicum II, and Practicum III.1); 23.8\% in other schools; and $24.2 \%$, within their immediate social context (families, friends, neighborhood, etc.).

The results obtained corroborate the effectiveness of the project and respond affirmatively to the research question proposed: the figure of teachers-prosumers favored the 
initial training of teachers in Didactics of Social Sciences from the approach of relevant social problems during lockdown.

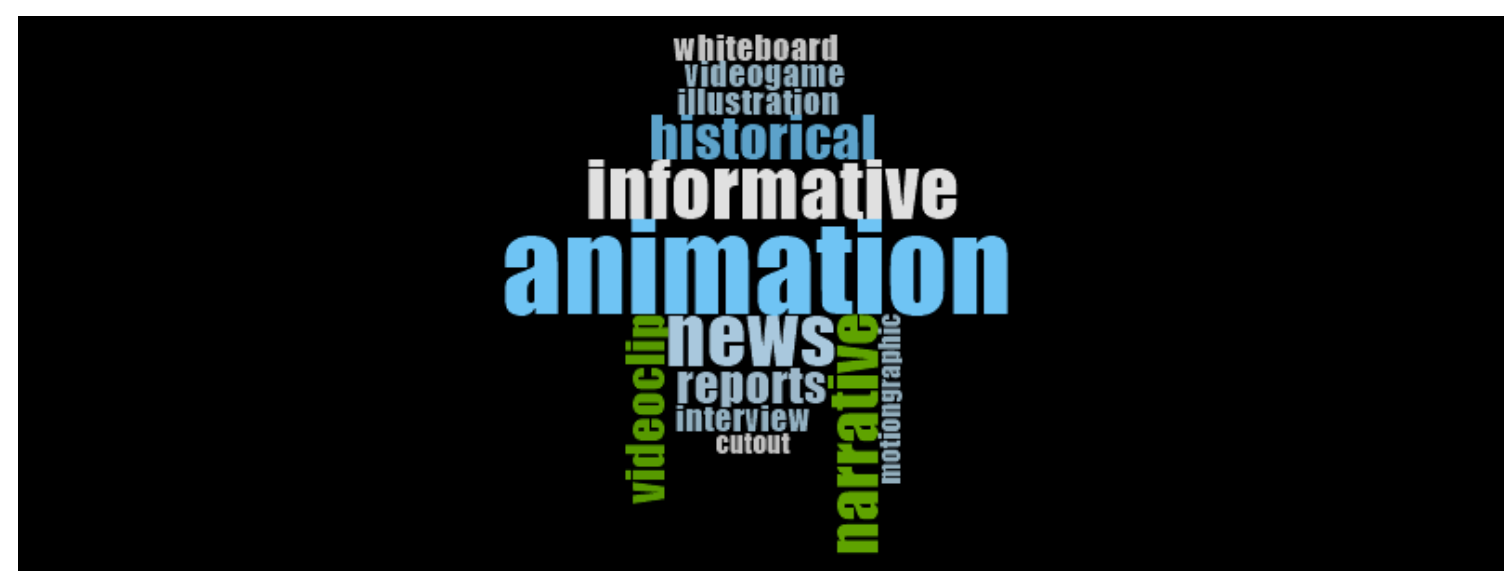

Figure 6. Types of educational videos from “Teachers vs. COVID-19" project.

\section{Discussion}

This study originates from a research question: Can the teacher-prosumer figure favor the initial training of teachers in Social Science Didactics from the perspective of the relevant social problems during the pandemic? To answer this question, two objectives were established.

The first of them was to test whether the figure of the teacher-prosumer contributes to improving the adaptation of face-to-face teaching to the virtual modality of the didactic course of social sciences of the Degree in Primary Education during lockdown. The student body turned from consumer to prosumer, feeling that they were not a passive teacher figure but a critical knowledge-creating agent. To configure this figure of teacher-prosumer, the promotion of digital skills and the use of social networks were essential. As previous research has shown, ICT can be used as tools that enhance the creativity of teachers in initial training stages [47]; improving teaching processes and constituting one of the basic competencies for citizenship [48]. The students, according to their members, their interests, their abilities, and their hobbies, made videos based on animations, video clips, video games, news, interviews, etc.; there were even students who dared to sing, compose, interpret, report, dance, etc. Therefore, we can say that creating the figure of teacherprosumer was a wise decision to adapt the Didactics of Social Sciences subject to the online mode.

"What I have liked the most is undoubtedly being able to create something that is useful for primary school students, to create a project that primary school students can understand, feel identified with, empathize, and relate knowledge based on what they are experiencing. That was the best gift that the course gave to me. The first day, when I learned what the course would be about and the great initiative that was going to be carried out, I literally ran, excited to tell it to my mother (a teacher). My opinion and my expectations about this project have not changed, I am very satisfied and happy with the result. I have learned to take advantage of obstacles. This pandemic seemed to be an obstacle and an immense problem to continue educating and teaching and it has turned out to be the opposite, an incredible opportunity for renewal and educational improvement, a challenge. I have no doubt that education, whatever happens, will always be the best resource to improve the world. I would like to thank you for your good work, dedication and involvement on the subject and education. Thank you for being such good teachers and for knowing how to see how we could contribute 
pertaining to the needs of primary school students and for unifying everything in such an initiative, thank you". (Student Group D)

However, we must explain that such a figure has worked because they acted as a group, that is to say, the creation of educational videos was the task of a group of students. This allowed students who did not have good connectivity and/or could not have computers to take charge of other functions within the group. In addition, the students themselves acknowledge in the post-test that they would rather have carried out this same project in person because they would have enjoyed much more personal contact with their classmates. In this respect, the objective is met because the idea of teacher-prosumer is transformed from individual to collective, promoting the idea of a shared and cooperative education.

On the other hand, in the assessment of "Teachers Versus COVID-19" in the post-test, the majority of the students said that they would have liked to have done the project in person because they missed human contact. Likewise, such comments corroborate the idea that this project, designed from a virtual teaching perspective, could be applied to face-to-face teaching, a fact that was not expected by us and which resulted in this project being evaluated as versatile.

Regarding the second objective, that is, to analyze the production of content in social networks by the students of the Degree in Primary Education taking into account the objectives of sustainable development, we can corroborate its compliance. We proposed to consider the SDGs because, in the context of the pandemic, it was a priority of the teaching team that the students felt that all adversity is an opportunity for the improvement of society. The students assimilated the SDGs from an active commitment to the social problems they were experiencing. In fact, as observed in the contrast between the pre-test and post-test results, the students went from a scant reflection on their own active and committed role as teachers in initial training to a considerable increase, reaching more than 180 students who considered they did have an active role during the pandemic. The creation of content associated with the official social sciences curriculum and its link with relevant social problems achieved a change in the simplistic idea that the students had understood the subject of social sciences. (CGPP1) We have compiled the testimonies of four students from the four class-groups that constitute the sample in response to the question: Why teach social sciences? (Table 2).

Table 2. Students' opinions about the teaching of social sciences.

\begin{tabular}{|c|c|c|}
\hline \multirow{2}{*}{ Students } & Pre-Test & Post-Test \\
\hline & Why Teach Social Sciences? & Why Teach Social Sciences? \\
\hline Student_Group A & $\begin{array}{l}\text { It is necessary because we live in society and } \\
\text { we must know how to perform in it and } \\
\text { ensure that students learn how to perform } \\
\text { in it. }\end{array}$ & $\begin{array}{l}\text { By teaching social sciences, we help students to understand } \\
\text { the social reality of the present and the past, favoring a } \\
\text { critical sense when questioning historical facts. It is } \\
\text { important to teach social sciences in order to transform } \\
\text { reality and analyze relevant social problems, transmitting to } \\
\text { students the values of the democratic society in which we } \\
\text { find ourselves. }\end{array}$ \\
\hline Student_Group B & $\begin{array}{l}\text { So that the students question themselves and } \\
\text { know where social sciences it comes from, } \\
\text { and the reason for things. }\end{array}$ & $\begin{array}{l}\text { Teaching social sciences involves making students think } \\
\text { about what happened throughout different times, as well as } \\
\text { making them empathize with it and everything learned can } \\
\text { be carried out in their daily lives. They must learn the } \\
\text { contents from the perspective of reality, giving it a meaning } \\
\text { and being able to reflect on the situation as if they were the } \\
\text { ones living it. }\end{array}$ \\
\hline
\end{tabular}


Table 2. Cont.

\begin{tabular}{lll}
\hline Students & Pre-Test & Post-Test \\
\cline { 2 - 3 } & Why Teach Social Sciences? & Why Teach Social Sciences? \\
\hline Student_Group C & $\begin{array}{l}\text { Think that teaching social sciences is essential for the } \\
\text { hu-man being and the different interactions } \\
\text { carried out in the society which they live in. } \\
\text { addition to promoting many of the basic skills that students } \\
\text { must acquire throughout their educational stage, } \\
\text { encourages critical and reflective thinking; making the } \\
\text { students understand what is happening around them and } \\
\text { knowing how to act in the best possible way. Finally, we } \\
\text { cannot forget that students not only learn and evolve } \\
\text { pertaining to what the current situation is all about, but also } \\
\text { understand that things or situations are like this for a } \\
\text { reason, that is, a cause-consequence relationship. }\end{array}$ \\
& $\begin{array}{l}\text { As we have seen with the project carried out, this subject is } \\
\text { very important so that students have access to the events } \\
\text { that occur and that take place in the world in which they } \\
\text { live, in order to understand what is happening and avoid } \\
\text { feelings such as fear of the unknown. }\end{array}$ \\
\hline
\end{tabular}

Among the limitations of this study, we must state that it would have been necessary to have information on the opinion of the videos that were shared and viewed by teachers and primary school students in the schools. Despite the rigorous monitoring that the teaching team carried out of the videos generated by teachers in initial training, we think that it would have been enriching for this research to know in a broad and detailed way, the opinions of teachers and students, through questionnaires and interviews, for the evaluation of the educational videos. In relation to the students, it would have been interesting to have evidence of whether the students understood the educational videos; to know if an adequate learning process of the content required for that educational level where the video was projected was achieved; and to know the degree of motivation that the educational videos generated in the students. With regard to the teachers, it would have been necessary to know whether the teachers considered that the educational videos were suitable for explaining the content of the educational levels chosen by the different groups of students; and whether these educational videos could be considered a good educational resource for explaining social science content in the context of the pandemic to other future courses

In short, taking into account the results of this research, the figure of teacher-prosumer favored the initial training of teachers in Didactics of Social Sciences from the approach of relevant social problems during the pandemic. We would like to end with the opinion of a student about the "Teachers Versus COVID-19" project which represents the general perception that the students had about the evaluation of that project and which allows us to give way to the conclusions of the study:

"Teaching is not transferring knowledge, but creating possibilities for your own production or construction", said Paulo Freire. Yes, I definitely think it has been that way thanks to the incredible project that we have built together. With the motto of "Teachers Versus COVID-19" we have committed ourselves, despite the new and complicated situation we were facing, not to stop education, to squeeze it to the maximum in order to take advantage of the problems in which we found ourselves perceive them as a challenge, a starting point, a push forward and motivation to reinforce the education and learning of many primary school students in terms of content of the formal and hidden curriculum in the area of social sciences, relating emotions and the experiences that the students are living with other moments in history, other values, knowledge and content that were within the teaching planning in this area. Personally, I believe that it is 
the best way to learn something, to make sense of what is taught from what is lived. (Student_Group A)

\section{Conclusions}

In short, this work corroborates the importance of digital skills [48] and socio-emotional skills [49] in adapting face-to-face to virtual education delivery during the pandemic, which is fundamental in terms of acknowledging the "Teachers vs. COVID-19" project as a good teaching practice within Malaga University. The empathetic competences which were generated sparked the students' interest in making inclusive videos, and professional sign language interpreters even took part. Furthermore, teachers from other levels of the education system also participated in creating videos, as did the families of the students themselves by appearing in the audiovisual productions. The virtuality and sense of responsibility felt by the pre-service trainee teachers were fundamental in strengthening awareness of the SDGs and acquiring a social and citizen commitment to the education community, at a time when children aged 6 to 12 had to learn social sciences while in full lockdown. In this respect, it was crucial for the students to develop their ability to represent narratives of the past and their relationship with their own present, moving away from the traditional history-memorization of the past link, in favor of thinking historically [50].

Due to the success of the project, we are currently developing a second part called "Teachers vs. Post-COVID-19: an audiovisual and interdisciplinary educational project for a pandemic". With the aim of adding the educational, citizen, and human responsibility that we took on in the context of the COVID-19 pandemic, this present project is expanded in an interdisciplinary way by encompassing several degree courses and including the bilingual teaching specialization Practicum III and the final dissertation, as well as the degrees in Early Childhood and Primary Education, and postgraduate levels, specifically, the Master's degree in Compulsory Secondary Education and Bachillerato, within the specializations in social sciences and drawing, visual, and plastic arts. The model of teacher-prosumer gives rise to a professional profile of teachers as researchers in the virtual classroom, added to those defined by Estepa [51], as practical, reflective, critical, and committed teachers who cooperate and work together, and as educators for citizen participation, beyond being a mere transmitter of subjects. Therefore, there is a need for teacher training to adopt a critical component that will enable future teachers to develop the capacity to move through and transfer this content, with teachers becoming "critical, committed and socially responsible" agents [52].

It should be noted that the acquisition of digital skills was not only an achievement for the students of the Degree in Primary Education; it was also a challenge for the university lecturers. This was the first time that the teachers had devised and produced their own educational video [53]. This was decisive in the understanding and dissemination of the project at its inception, both for the class groups and for the education community itself in the province of Malaga, having a national impact [54-56]. As Garcia et al. [57] state, the use of ICT in Spanish universities is infrequent due to multiple factors such as the level of technological competence, age, and experience. Such factors were precisely the ones that explained the situation of the teachers themselves. The project was, therefore, an impetus for the teachers to progress from digital immigrants to digital natives [58]. We would also like to emphasize that, given the space constraints of this paper and that gender equality is one of the SDGs, it would be interesting to analyze the project from a gender perspective. Finally, beyond our shared goals, "Teachers vs. COVID-19" became a project that emotionally united us as a group in an uncertain situation for both teachers and students in the course of Didactics of Social Sciences.

As a future line of research, "Teachers Versus COVID-19" is a project that corroborates the approaches of this research in the introduction of the figure of teachers in initial training as prosumers for two fundamental reasons. The first is that the figure of the teacherprosumer is necessarily constructed from a multimodal approach $[59,60]$ as a pedagogical approach. Bearing in mind the digital society in which we find ourselves, the teaching- 
learning processes must assume that a hegemony of scriptural-centrism can no longer predominate; and literacy does not only involve knowing how to read and write, but also a multimodal literacy [61-63]. By using different modes in the teaching of the social sciences (written, kinesics, visual, sound, audiovisual, etc.), the possibility is opened up for post-pandemic education that enables the students to find their element, as Ken Robinson pointed out [64], that enhances their skills, through the development of both critical and creative thinking. In the creation of educational videos, each student had to carry out an introspective process to assert the skills and talents they had that could be used to make such artefacts, an opportunity that had not always been given to them at other levels of education and which, in a way, lead to a major change: from a process of alienation to a rewarding and motivating challenge.

Moving now to the second reason, these skills are diverse as our students are diverse. Therefore, this study confirms that the figure of teacher-prosumer is not individual but a group one. Each student had different domains as well as digital, critical, creative, linguistic, and socio-emotional skills and competences. It was precisely the sum of all this in a group of students that generated the effectiveness of the teacher-prosumer figure. Following Li-Ching Ho and Keith C. Barton's [65] concept of critical harmony, we can say that this project fostered a harmonious critical process among the teaching staff, understanding it as "a process of interaction in which diverse elements come together in a balanced and integrated way, such that the whole becomes greater than the sum of its parts" (p. 2).

Therefore, the figure of teacher-prosumer as a teaching training proposal shows the need for an education committed to social change and to the construction of a sustainable world in the immediate future that thinks and acts "glocally", and with this, to achieve another world in which a thousand worlds are possible within mutual recognition and equality [66], and these worlds will be digital (online education) but definitely human (face-to-face education).

Author Contributions: Conceptualization, L.T.-C. and E.I.C.-G.; methodology, E.I.C.-G. and L.T.-C.; software, E.I.C.-G. and L.A.-L.; validation, L.T.-C., E.I.C.-G. and L.A.-L.; formal analysis, L.T.-C.; investigation, L.T.-C., E.I.C.-G. and L.A.-L.; resources, L.T.-C., E.I.C.-G. and L.A.-L.; data curation, L.T.-C. and E.I.C.-G.; writing-original draft preparation, L.T.-C., E.I.C.-G., and L.A.-L.; writingreview and editing, L.T.-C. and E.I.C.-G.; visualization, L.T.-C. and E.I.C.-G.; supervision, L.T.-C.; project administration, L.T.-C.; funding acquisition, L.T.-C. All authors have read and agreed to the published version of the manuscript.

Funding: This research was funded by the Ministry of the Economy, Industry and Competitiveness of Spain, grant number FEM2017-83302-C3-3-P" and University of Malaga, grant number PIE 19-210.

Institutional Review Board Statement: Not applicable.

Informed Consent Statement: Not applicable.

Data Availability Statement: Not applicable.

Conflicts of Interest: The authors declare no conflict of interest.

\section{References}

1. Triviño-Cabrera, L. Utopia, historical thought and multimodality for the media empowerment of the pre-service trainee history teachers. Int. J. Res. Hist. Didact. Hist. Educ. Hist. Cult. (JHEC) 2019, 40, 129-140.

2. Triviño-Cabrera, L.; Bernárdez-Rodal, A.; Velázquez-Felipe, A. The @Filosoclips project: Teaching feminist philosophy through popular culture in Spain. Gend. Educ. 2020, 1-15. [CrossRef]

3. Bruns, A. The Future is User-led: The Path Towards Widespread Produsage. Fibreculture J. 2008, 11, 68-77.

4. Genz, S. My Job is Me. Fem. Media Stud. 2015, 15, 545-561. [CrossRef]

5. Bunes, M.; Blesa, B.; González, A.; González, J.J.; Pintado, M.; Tornel, M. Valores asociados a las experiencias del cuerpo en las comunicaciones de los jóvenes. Prism. Soc. 2016, 15, 34-83.

6. Merelo, J.; Tricas, J. La irresistible ascensión del WhatsApp. ReVisión 2012, 6, 3-4.

7. Sabater Fernández, C. La vida privada en la sociedad digital. La exposición pública de los jóvenes en internet. Aposta 2014, 61, $1-32$. 
8. Asociación para la Investigación en Medios de Comunicación. Cuestionario $22^{\mathrm{a}}$ Encuesta AIMC a Usuarios de Internet, 2019. Navegantes en la Red. Available online: http://download.aimc.es/aimc/Rub9aYt/macro2019_cuest.pdf (accessed on 20 December 2020).

9. Royal Society for Public Health. \#Status Of Mind. Social Media and Young People's Mental Health and Wellbeing. 2017. Available online: https:/ / www.rsph.org.uk/static/uploaded/d125b27c-0b62-41c5-a2c0155a8887cd01.pdf (accessed on 20 December 2020).

10. Hall, S. Notes on Deconstructing ‘The Popular'. In Popular Culture. A Reader; Guins, R., Cruz, O.Z., Eds.; Sage: Newbury Park, CA, USA, 1981; pp. 64-71.

11. Storey, J. Teoría Cultural. Cultura Popular; Octaedro: Barcelona, Spain, 2012.

12. Walker, T. Adventures in Metropolis: Popular Culture in Social Studies. In Social Studies. The New Generation. Researching in the Postmodern; Segall, A., Heilman, E., Cherryholmes, C.H., Eds.; Peter Lang: Bern, Switzerland, 2006.

13. Freire, P.; Macedo, D. Alfabetización, Lectura de la Palabra y Lectura de la Realidad; Paidós: Barcelona, Spain, 1989.

14. Hess, D. Controversies about Controversial Issues in Democratic Education; Routledge: New York, NY, USA, 2009.

15. Legardez, A.; Simonneaux, L. (Eds.) L'école à L'épreuve de L'actualité; ESF: Issy-les-Moulineaux, France, 2006.

16. Tutiaux-Guillon, N. Les qüestions socialment vives, un repte per a la historia i la geografía escolars. In Les Qüestions Socialment Vives il 'Enseyament de Les Ciènces Socials; Pagès, J., Santisteban, A., Eds.; Universitat Autònoma de Barcelona: Bellaterra, Spain, 2011.

17. Yves, A.; Barthes, A. De la question socialement vive à l'objet d'enseignement: Comment légitimer des savoirs incertains? Les Doss. Des Sci. L'éducation 2013, 29, 33-44. [CrossRef]

18. Benejam, P.; Pagès, J. Enseñar y Aprender Ciencias Sociales, Geografía e Historia en la Educación Secundaria; ICE/Horsori: Barcelona, Spain, 1997.

19. Pagès, J. La formación del pensamiento social. In Enseñar y Aprender Ciencias Sociales, Geografía e Historia en la Educación Secundaria; Benejam, P., Pagès, J., Eds.; ICE/Horsori: Barcelona, Spain, 1997; pp. 152-164.

20. Zhou, L.; Li, F.; Wu, S.; Zhou, M. 'School's Out, But Class' On', the Largest Online Education in the World Today: Taking China's Practical Exploration During The COVID-19 Epidemic Prevention and Control as an Example. Best Evid. Chin. Edu. 2020, 4. [CrossRef]

21. General Assembly of the United Nations. Transforming Our World: The 2030 Agenda for Sustainable Development. 2015. Available online: https:/ /www.un.org/ga/search/view_doc.asp?symbol=A/RES/70/1\&Lang=E (accessed on 20 December 2020).

22. Giroux, H.; Rivera-Vargas, P.; Passeron, E.; Pandémica, P. Reproducción Funcional o Educación Antihegemónica. Rev. Int. Educ. Para Justicia Soc. 2020, 9. Available online: https:/ / revistas.uam.es/riejs/article/view/12199 (accessed on 20 December 2020).

23. Huang, R.H.; Liu, D.J.; Tlili, A.; Yang, J.F.; Wang, H.H. Handbook on Facilitating Flexible Learning during Educational Disruption: The Chinese Experience in Maintaining Undisrupted Learning in COVID-19 Outbreak; Smart Learning Institute of Beijing Normal University: Beijing, China, 2020.

24. Reimers, F.; Scleicher, A. A Framework to Guide an Education Response to the COVID-19 Pandemic of 2020; OECD: Paris, France, 2020; Available online: https:/ / globaled.gse.harvard.edu/files/geii/files/framework_guide_v1_002.pdf (accessed on 20 December 2020).

25. Save the Children (2020). COVID-19: Cerrar la Brecha. Impacto Educativo y Propuestas de Equidad Para la Desescalada. Save the Children. Available online: https://www.savethechildren.es/sites/default/files/2020-05/COVID19Cerrarlabrecha.pdf (accessed on 20 December 2020).

26. Trujillo-Sáez, F.; Fernández-Navas, M.; Montes-Rodríguez, M.; Segura-Robles, A.; Alaminos-Romero, F.J.; Postigo-Fuentes, A.Y. Panorama de la Educación en España Tras la Pandemia de COVID-19: La Opinión de la Comunidad Educativa; FAD: Madrid, España, 2020. [CrossRef]

27. Trujillo-Sáez, F. (Ed.) Aprender y Enseñar en Tiempos de Confinamiento; Los Libros de la Catarata: Madrid, Spain, 2020.

28. UNESCO. Education: From Disruption to Recovery. 2020. Available online: https://en.unesco.org/covid19/educationresponse (accessed on 20 December 2020).

29. UNICEF. Framework for Reopening Schools. 2020. Available online: https://www.unicef.org/media/71366/file/Frameworkfor-reopening-schools-2020.pdf (accessed on 20 December 2020).

30. Fonseca, J. Aprendizaje Servicio como método de enseñanza para la formación ciudadana y profesional responsable. Una propuesta de Responsabilidad Social Universitaria en la UNICACH. DEDiCA Rev. Educ. Humanid. (Dreh) 2020. [CrossRef]

31. Anderson, T. Design-based research and its application to a call center innovation in distance education. Can. J. Learn. Technol. 2005, 31, 69-84. Available online: http:/ / www.jofde.ca/index.php/jde/article/view/18/552 (accessed on 20 December 2020). [CrossRef]

32. Easterday, M.W.; Lewis, D.G.R.; Gerber, E.M. The logic of design research. Learn. Res. Pract. 2018, 4, 131-160. [CrossRef]

33. Brown, A.L. Design experiments: Theoretical and methodological challenges in creating complex interventions in classroom settings. J. Learn. Sci. 1992, 2, 141-178. [CrossRef]

34. Collins, A. Toward a design science of education. In New Directions in Educational Technology; Scanlon, E., O'Shea, T., Eds.; Springer: Berlin/Heidelberg, Germany, 1992; pp. 15-22.

35. Reeves, T.C.; Herrington, J.; Oliver, R. Authentic Activities and Online Learning; ECU Publications: Greenville, NC, USA, 2002.

36. Barab, S.; Squire, K. Design-Based Research: Putting a stake in the ground. J. Learn. Sci. 2004, 13, 1-14. [CrossRef] 
37. Wang, F.; Hannafin, M.J. Design-based research and technology-enhanced learning environments. Educ. Technol. Res. Dev. 2005, 53, 5-23. [CrossRef]

38. Cruz, I.M.; Acebal, M.C.; Cebrián, D.; Blanco, A. El juego de rol como estrategia didáctica para el desarrollo de la conciencia ambiental. Una Investigación Basada en el Diseño. Rev. Educ. Ambient. Sostenibilidad 2020, 2. [CrossRef]

39. DBRC (The Design Based Research Collective). Design-based research: An emerging paradigm for educational inquiry. Educ. Res. 2003, 32, 5-8. [CrossRef]

40. Cobb, P.; Confrey, J.; diSessa, A.; Lehrer, R.; Schauble, L. Design experiments in educational research. Educ. Res. 2003, 32, 9-13. [CrossRef]

41. Van den Akker, J. Principles and methods of development research. In Design Methodology and Developmental Research in Education and Training; Van den Akker, J., Nieveen, N., Branch, R.M., Gustafson, K.L., Plomp, T., Eds.; Kluwer Academic Publishers: Amsterdam, The Netherlands, 1999; pp. 1-14.

42. Glaser, B.; Strauss, A. The Discovery of Grounded Theory; Aldine Press: Venice, Italy, 1963.

43. Prats, J.; Santacana, J. Veinte invariables para la enseñanza de la historia. In Ciencias Sociales, Ciudadania y Sociedad Digital: Reflexiones Desde la Educación; Prats, J., Ed.; Trea: Alexandria, VA, USA, 2020; pp. 13-26.

44. Rüsen, J. Historical consciousness: Narrative structure, moral function and ontogenetic development. In Theorizing Historical Consciousness; Seixas, P., Ed.; University of Toronto Press: Toronto, ON, Canada, 2004; pp. 63-85.

45. Docentes Vs. Covid19. DocentesVsCOVID-19 [Channel]. Available online: https://www.youtube.com/channel/UCI1NtiZ4 enltt53pPMA885g (accessed on 2 April 2020).

46. Sadio-Ramos, F.J.; Ortiz-Molina, M.A.; Villodre, M.M.B. La formación del profesorado de Música para potenciar la creatividad desde la utilización de las TIC: Una experiencia biográfica. Rev. Electrónica Interuniv. Form. Profr. 2020, 23, 155-166. [CrossRef]

47. Artacho, E.; Martínez, T.; Martín, J.O.; Marín, J.M.; García, G. Teacher Training in Lifelong Learning-the Importance of Digital Competence in the Encouragement of Teaching Innovation. Sustainability 2020, 12, 2852. [CrossRef]

48. Magaña, E.C.; Rivas, E.S.; Palmero, J.R.; Rodríguez, J.S. (Eds.) La Tecnología Como eje Del Cambio Metodológico; UMA Editorial: Málaga, España, 2020.

49. Hadar, L.L.; Ergas, O.; Alpert, B.; Ariav, T. Rethinking teacher education in a VUCA world: Student teachers' social-emotional competencies during the Covid-19 crisis. Eur. J. Teach. Educ. 2020. [CrossRef]

50. Gómez-Carrasco, C.; Miralles-Martínez, P. Pensar históricamente o memorizar el pasado? La evaluación de los contenidos históricos en la educación obligatoria en España. Rev. Estud. Soc. 2015, 52, 52-68. [CrossRef]

51. Giménez, J.E. La formación del profesorado para enseñar la participación en el Grado de Maestro y en el Máster en Profesorado de Secundario. In Educar Para la Participación Ciudadana en la Enseñanza de las Ciencias Sociales; de-Alba-Fernández, N., García-Pérez, F., Fernández, A.S., Eds.; Universidad de Huelva: Huelva, Spain, 2012; pp. 211-220.

52. Giroux, H.; McLaren, P. Sociedad, Cultura y Educación; Miño y Dávila Editores: Tacuarí, Buenos Aires, 1998.

53. Docentes Vs. Covid19. DocentesVsCOVID-19 [Videol]. Available online: https://www.youtube.com/watch?v=6C_okU9tgA\&t= 29s (accessed on 2 April 2020).

54. Europa Press Unos 300 Estudiantes de la Universidad de Málaga Explican la Realidad de la Pandemia a Menores con Vídeos Educativos. Europa Press. Available online: https:/ /www.europapress.es/andalucia/malaga-00356/noticia-300-estudiantesuniversidad-malaga-explican-realidad-pandemia-menores-videos-educativos-20200503110948.html (accessed on 3 May 2020).

55. La Vanguardia. Coronavirus.-Unos 300 Estudiantes de la UMA Explican la Realidad de la Pandemia con Vídeos Educativos. La Vanguardia. Available online: https:/ / www.lavanguardia.com/local/sevilla/20200503/48935727901/coronavirus--unos-300estudiantes-de-la-uma-explican-la-realidad-de-la-pandemia-con-videos-educativos.html (accessed on 3 May 2020).

56. Sala de Prensa de la Universidad de Málaga. 300 estudiantes del Grado en Educación Primaria crean vídeos sobre el COVID-19 para alumnado de entre 6 y 12 años. Universidad de Málaga. Available online: https:/ / www.uma.es/sala-de-prensa/noticias / 300-estudiantes-del-grado-en-educacion-primaria-crean-videos-sobre-el-covid-19-para-alumnado-de-entre-6-y-12-anos / (accessed on 20 April 2020).

57. García, S.; Aznar-Díaz, I.; Cáceres-Reche, M.P.; Torres, J.M.; Romero-Rodríguez, J.-M. Systematic Review of Good Teaching Practices with ICT in Spanish Higher Education Trends and Challenges for Sustainability. Sustainability 2019, 11, 7150. [CrossRef]

58. Prensky, M. Digital Natives, Digital Immigrants. In On the Horizon; MCB Univeristy Press: Bingley, UK, 2001.

59. Kress, G.; Van Leeuwen, T. Multimodal Discourse. The Modes and Media of Contemporary Communication; Arnold: London, UK, 2001.

60. Kress, G. Multimodality: A Social Semiotic Approach to Contemporary Communication; Routledge: Abingdon, UK, 2010.

61. González-García, J. Alfabetización multimodal: Usos y posibilidades. Campo Abierto 2013, 32, 91-113.

62. Lacambra, A.M.M.; Ansorena, A.A. Empleo de la fotografía para desarrollar la alfabetización multimodal. propuesta de análisis. Didácticas Específicas 2017, 80-95. Available online: https://revistas.uam.es/didacticasespecificas/article/view/6756 (accessed on 20 December 2020).

63. Lim, F.V. Developing a systemic functional approach to teach multimodal literacy. Funct. Linguist 2018, 5, 13. [CrossRef]

64. Robinson, K. Finding Your Element: How to Discover Your Talents and Passions; Penguin Press: London, UK, 2014.

65. Ho, L.C.; Barton, C. Critical harmony: A goal for deliberative civic education. J. Moral Educ. 2020. [CrossRef]

66. Moreno-Fernández, O. Educación y ciudadanía planetaria. Concepciones del alumnado participante en programas educativos andaluces. Pedagog. Soc. Rev. Interuniv. 2015, 26, 229-261. [CrossRef] 